\title{
PENGARUH BIMBINGAN BELAJAR BAGI SISWA DALAM MENGHADAPI PENILAIAN AKHIR SEMESTER PADA MATA PELAJARAN BIOLOGI
}

\author{
Ade Suryanda*1, Eka Putri Azrai ${ }^{2}$, Leni Melisa ${ }^{3}$ \\ ${ }^{1,2,3}$ Program Studi Pendidikan Biologi FMIPA Universitas Negeri Jakarta \\ Jl. Rawamangun Muka, Pulo Gadung, Jakarta Timur, DKI Jakarta, 13220 \\ email : *11asuryanda@unj.ac.id; ${ }^{2}$ ekaputri@unj.ac.id; ${ }^{3}$ Lenimelisa2@gmail.com
}

\begin{abstract}
ABSTRAK
Kesiapan merupakan faktor penting yang harus dimiliki seseorang agar dapat melakukan aktifitas dengan matang dan optimal. Siswa harus memiliki kesiapan dalam menghadapi ujian akhir semester. Penelitian ini bertujuan untuk mengetahui pengaruh keikutsertaan siswa dalam bimbingan belajar terhadap kesiapan siswa dalam menghadapi penilaian akhir semester. Penelitian dilakukan di SMAN 1 Cibinong pada bulan April sampai Mei 2019. Metode penelitian yang digunakan adalah expost facto. Populasi dari penelitian ini adalah seluruh siswa kelas XI di SMAN 1 Cibinong. Sampel yang digunakan dalam penelitian ini adalah siswa kelas XI jurusan IPA sebanyak 70 siswa yang diambil secara proportional random sampling. Setelah diuji prasyarat, data penelitian berdistribusi normal dan homogen. Hasil uji hipotesis yang dilakukan menggunakan rumus T- Smith Satterthwaite pada data dua pekan sebelum ujian diperoleh nilai t Smith- Satterthwaite 0,47 . Hal ini berarti terdapat pengaruh keikutsertaan siswa dalam bimbingan belajar terhadap kesiapan menghadapi PAS biologi. Pada data yang diambil satu hari sebelum penilaian diperoleh nilai t Smith-Satterthwaite 0,85 yang artinya tidak terdapat pengaruh keikutsertaan siswa dalam bimbingan belajar terhadap kesiapan menghadapi ujian akhir semester biologi.
\end{abstract}

Kata Kunci: bimbingan belajar, kesiapan, siswa, penilaian akhir semester

\begin{abstract}
Readiness is an important factor that every person must have in order to be able to carry out activities thoroughly and optimally. Students must have readiness in facing the final exam. This study aims to determine the effect of student participation in tutoring on student readiness in facing the final exam. The research was conducted at Public High School Cibinong. The research method used was ex post facto. The population of this study was all students of class XI in Public High School Cibinong. The sample used in this study was 70 XI students majoring in Natural Sciences who were taken by proportional random sampling. After testing the prerequisites, the research data is normally distributed and homogeneous. The results of the hypothesis test conducted using the Smith-Satterthwaite formula in the data two weeks before the test obtained the Smith-Satterthwaite $t$ value of 0.47. This means that there is an effect of student participation in tutoring on readiness to face biology final exam test. In the data taken one day before the assessment the Smith-Satterthwaite t value was obtained 0.85 which means that there was no influence of student participation in tutoring on the readiness to face the final examination of the biology.
\end{abstract}

Kata Kunci :: tutoring, readiness, students, final exam 


\section{PENDAHULUAN}

Pendahuluan berisi tentang latar belakang Penilaian/asesmen merupakan bentuk akuntanbilitas penyelenggara pendidikan kepada pihak-pihak yang berkepentingan. Penilaian/asesmen hasil belajar peserta didik dilakukan oleh pendidik untuk memantau proses, kemajuan, dan perbaikan hasil belajar peserta didik secara berkesinambungan (Depdiknas, 2003; Kemendikbud, 2016; Ahmad, 2015; Arifin, 2012; Asrul, Rusydi, \& Rosinta, 2015). Sehingga pemerintah mengadakan penilaian/asesmen yang dilakukan untuk mengukur pencapaian kompetensi siswa secara berkelanjutan dalam proses pembelajaran untuk memantau kemajuan dan perbaikan hasil belajar siswa. penilaian adalah suatu proses untuk memperoleh informasi yang digunakan untuk membuat keputusan tentang peserta didik. penilaian dapat didefinisikan sebagai suatu proses atau kegiatan yang sistematis dan berkesinambungan untuk mengumpulkan informasi tentang proses dan hasil belajar peserta didik dalam rangka membuat keputusan-keputusan berdasarkan kriteria dan pertimbangan tertentu (Arifin, 2012; Asrul et al., 2015; Isaacs, Zara, Herbert, Coombs, \& Smith, 2013). Salah satu bentuk penilaian/asesmen yang diselenggarakan pemerintah adalah ujian penilaian akhir semester (PAS) (Kemendikbud, 2016).

Ujian penilaian akhir semester (PAS) bertujuan untuk mengukur pencapaian hasil kompetensi belajar siswa yang diajarkan oleh guru atau pendidik selama satu semester. Selain itu, PAS merupakan bentuk evaluasi hasil belajar siswa dilakukan oleh pendidik untuk memantau proses, kemajuan, dan perbaikan hasil belajar siswa secara berkesinambungan PAS juga bisa untuk memantau kemajuan belajar siswa selama proses belajar berlangsung, untuk memberikan umpan balik (feedback) guna penyempurnaan program pembelajaran. PAS merupakan bentuk evaluasi hasil belajar siswa dilakukan oleh pendidik untuk memantau proses, kemajuan, dan perbaikan hasil belajar siswa secara berkesinambungan (Tyanurani, 2015)

Kesiapan dalam belajar merupakan suatu kondisi dimana seorang siswa sudah siap untuk melakukan aktivitas dengan penuh kesadaran untuk memperoleh pengetahuan, pemahaman, keterampilan, sikap dengan cara mengamati, meniru, latihan serta masuknya pengalaman baru pada siswa. kesiapan belajar merupakan suatu kesatuan usaha untuk melengkapi kemampuan yang dimilikinya dalam mengambil tindakan/memberi respon dari apa yang akan/sedang dihadapinya dalam belajar,salah satunya adalah kesiapan siswa dalam mengadapi PAS (Mulyani, 2013; Rizki, 2013; Sinta B, 2017).

Alternatif keikutsertaan bimbingan belajar (bimbel) merupakan salah satu persiapan yang dapat dilakukan oleh siswa dalam mempersiapkan ujian. Beratnya standar kelulusan yang diberikan oleh pemerintah dan persaingan antar siswa, menjadi alasan siswa untuk mencari tambahan materi di luar sekolah. Dengan mengikuti bimbingan belajar siswa dapat meningkatkan rasa percaya dirinya dan meningkatkan kesiapan siswa (Suhandis, Junaidi, Matsum, \& Asrati, 2014).

Bimbingan merupakan upaya pemberian bantuan kepada siswa dalam rangka mencapai perkembangannya yang lebih optimal sehinga dapat meningkatkan prestasi akademik siswa dan persiapan menghadapi PAS, sehingga dengan mengikuti bimbingan belajar (bimbel) dapat meningkatkan kesiapan siswa dalam menghadapi PAS (Berg, 2010; Suhandis et al., 2014; Yusuf \& Nurihsan, 2005). Siswa dituntut untuk memahami materi pelajaran yang telah diterimanya. Siswa yang merasa kesulitan belajarnya membutuhkan bimbingan belajar untuk lebih memudahkan memahaminya. Sehingga bimbingan belajar menjadi pilihan siswa sebagai sarana untuk mencapai prestasi sebaik mungkin dengan belajar lebih aktif. Penelitian ini ingin melihat pengaruh keikutan siswa dalam bimbingan belajar terhadap kesiapan dalam mengikuti PAS. Hal ini akan menggambarkan apakah penting bagi siswa untuk mengikuti bimbingan belajar demi 
menghadapi PAS.

\section{METODE}

Tujuan penelitian ini adalah untuk menganalisis pengaruh keikutsertaan siswa dalam bimbingan belajar terhadap kesiapan siswa dalam menghadapi PAS. Metode yang digunakan dalam penelitian ini yaitu metode penelitian expost facto. Dalam penelitian ini terdapat dua variabel, yaitu keikutsertaan siswa dalam bimbingan belajar sebagai variabel bebas dan kesiapan siswa dalam menghadapi PAS sebagai variabel terikat. Penelitian ini dilakukan di SMAN 1 Cibinong.

Analisis data pada penelitian ini meliputi uji prasyarat dan uji hipotesis. Uji normalitas dilakukan dengan menggunakan uji
Kolmogorov-Smirnov dan uji homogenitas dengan uji Bartlett pada $\alpha=0,05$. Uji hipotesis dilakukan dengan uji $\mathrm{t}$ Smith Satterthwaite

\section{HASIL DAN PEMBAHASAN}

\section{a. Skor Kesiapan Menghadapi PAS Biologi Siswa yang Mengikuti Bimbel (diambil 2 pekan sebelum penilaian)}

Kesiapan siswa dalam menghadapi PAS bagi yang mengikuti bimbel diperoleh data bahwa skor tertinggi sebesar 89, sedang skor terendah adalah 50 dengan rata-rata 70,23 dan simpangan baku sebesar 8,384. Sebaran skor dapat dilihat pada Gambar 1:

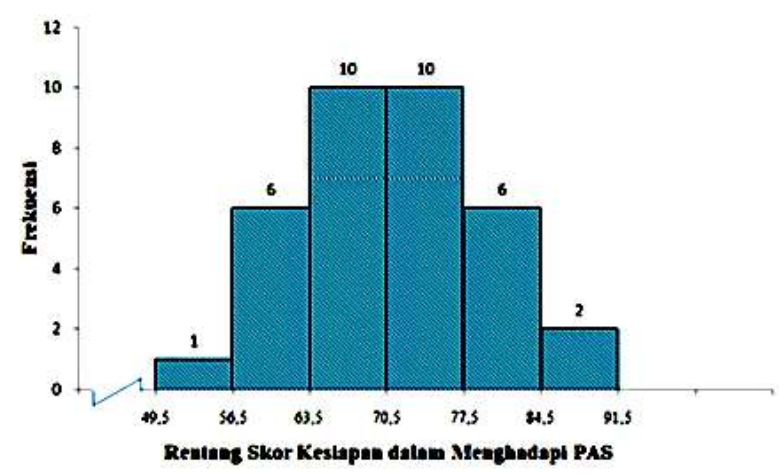

Gambar 1. Sebaran Skor Hasil Kesiapan Siswa yang Mengikuti Bimbel Menghadapi PAS Biologi (diambil 2 pekan sebelum penilaian)

b. Skor Kesiapan Menghadapi PAS Biologi Siswa yang Tidak Mengikuti Bimbel (diambil 2 pekan sebelum penilaian)

Data kesiapan siswa yang tidak mengikuiti bimbel adalah skor tertinggi mencapai 82 dan skor terendah adalah 59, dengan rata-rata sebesar 69,43, dan simpangan bakunya 5,548, Gambar 2 memperlihatkan sebaran skor kesiapan siswa yang tidak mengikuti bimbel.

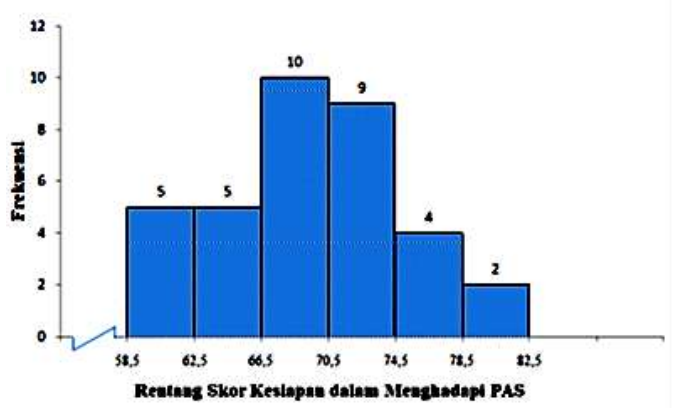

Gambar 2. Sebaran Skor Hasil Kesiapan Siswa yang Tidak Mengikuti Bimbel Menghadapi PAS Biologi (diambil 2 pekan sebelum penilaian) 
c. Skor Kesiapan Menghadapi PAS Biologi Siswa yang Mengikuti Bimbel (diambil 1 hari sebelum penilaian)

Pada data yang diambil 1 hari sebelum penilaian bagi siswa yang mengikuti bimbel diperoleh skor tertinggi adalah 93 dan skor terendah 60 dengan rata-rata sebesar 73,63 dan simpangan bakunya 7,179. Sebaran skor hasil penelitian tersebut dapat dilihat pada Gambar 3:

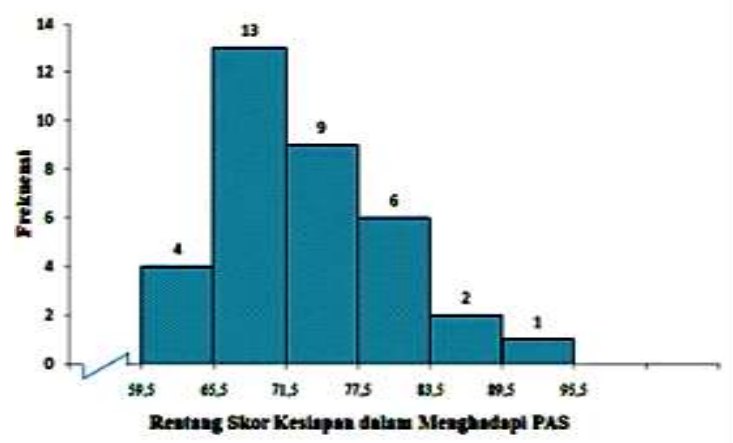

Gambar 3. Sebaran Skor Hasil Kesiapan Siswa yang Mengikuti Bimbel Menghadapi PAS Biologi (diambil 1 hari sebelum penilaian)

d. Skor Kesiapan Menghadapi PAS Biologi Siswa yang Tidak Mengikuti Bimbel (diambil 1 hari sebelum penilaian)

Dari data yang telah dikumpulkan tentang kesiapan siswa dalam menghadapi penilaian akhir semester biologi diperoleh skor tertinggi sebesar 88 sedang skor terendah 62 dengan rata-rata sebesar 72,26 dan simpangan bakunya 6,118. Sebaran skor tersebut dapat dilihat pada Gamabr 4.

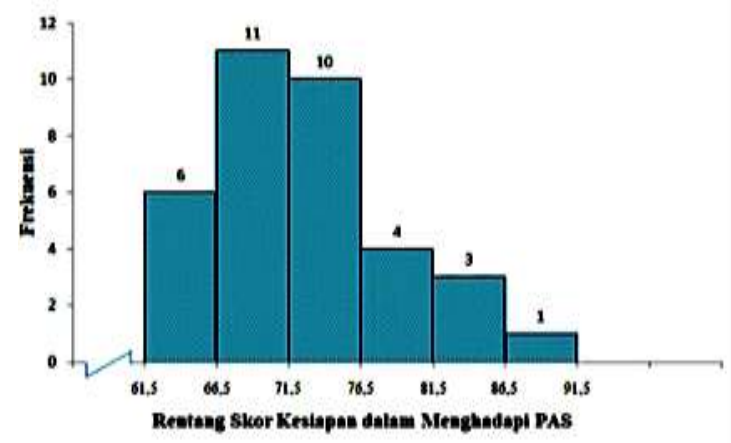

Gambar 4. Sebaran Skor Hasil Kesiapan Siswa yang Tidak Mengikuti Bimbel Menghadapi PAS Biologi (diambil 1 hari sebelum penilaian)

Berdasarkan hasil data di atas maka, berikut: dibuat tabel data perbandingan sebagai

Tabel 1. Skor Kesiapan Menghadapi PAS Biologi Siswa

\begin{tabular}{ccccc}
\hline & \multicolumn{2}{c}{ Mengikuti Bimbel } & \multicolumn{2}{c}{ Tidak Mengikuti Bimbel } \\
\hline & $\begin{array}{c}\text { 2 Pekan } \\
\text { sebelum } \\
\text { ujian }\end{array}$ & $\begin{array}{c}\text { 1 hari } \\
\text { sebelu } \\
\text { m } \\
\text { ujian }\end{array}$ & $\begin{array}{c}\text { Pekan } \\
\text { sebelu } \\
\text { m ujian }\end{array}$ & $\begin{array}{c}\text { 1 hari sebelum } \\
\text { ujian }\end{array}$ \\
\hline Nilai tertinggi & 89 & 93 & 82 & 88 \\
\hline
\end{tabular}




\begin{tabular}{ccccc}
\hline Nilai terendah & 50 & 60 & 59 & 62 \\
\hline Rata-rata & 70.23 & 73.63 & 69.43 & 72.26 \\
\hline kesiapan fisik & $19.97 \%$ & $\begin{array}{c}19.97 \\
\%\end{array}$ & $\begin{array}{c}11.78 \\
\%\end{array}$ & $19.45 \%$ \\
\hline $\begin{array}{c}\text { kesiapan } \\
\text { mental }\end{array}$ & $9.55 \%$ & $\begin{array}{c}10.96 \\
\%\end{array}$ & $6.48 \%$ & $9.63 \%$ \\
\hline $\begin{array}{c}\text { kesiapan } \\
\text { emosional }\end{array}$ & $4.76 \%$ & $8.56 \%$ & $5.26 \%$ & $8.30 \%$ \\
\hline $\begin{array}{c}\text { kesiapan } \\
\text { kebutuhan }\end{array}$ & $5.18 \%$ & $8.48 \%$ & $3 \%$ & $4.71 \%$ \\
\hline $\begin{array}{c}\text { kesiapan } \\
\text { pengetahuan }\end{array}$ & $21.43 \%$ & $\begin{array}{c}22.47 \\
\%\end{array}$ & $\begin{array}{c}13.09 \\
\%\end{array}$ & $21.12 \%$ \\
\hline
\end{tabular}

Penggunaan uji $t$ Smith-Satterthwaite disebabkan data berdistribusi normal namun tidak homogen.

Berdasarkan perhitungan Tabel 1, nilai rata-rata skor kesiapan siswa yang mengikuti bimbel yaitu sebesar 70,23 lebih besar jika dibandingkan rata-rata skor kesiapan siswa yang tidak mengikuti bimbel yaitu sebesar 69,49 pada pengambilan data 2 pekan sebelum PAS. Hal ini memperlihatkan bawah terdapat pengaruh keikutsertaan siswa dalam bimbingan belajar terhadap kesiapan siswa menghadapi PAS Biologi

Sedangkan pada pengambilan data 1 hari sebelum PAS, perhitungan nilai rata-rata skor kesiapan siswa yang mengikuti bimbel yaitu sebesar 73,63 tidak jauh berbeda dengan rata-rata skor kesiapan siswa yang tidak mengikuti bimbel yaitu sebesar 72,26. Berdasarkan hal tersebut disimpulkan bahwa tidak ada pengaruh pada kesiapan belajar antara siswa yang mengikuti bimbel maupun yang tidak.

Bimbingan belajar merupakan suatu usaha yang diberikan individu yang memiliki kemampuan khusus kepada individu lain baik dilakukan secara perkelompok ataupun perindividu. Dalam penelitian ini peneliti ingin mengetahui apakah terdapat pengaruh keikutsertaan siswa dalam bimbel terhadap kesiapan siswa dalam menghadapi PAS Biologi. Oleh karena itu peneliti memberikan instrumen kepada sampel sebanyak dua kali.

Pengambilan data pertama dilakukan dua pekan sebelum siswa menghadapi PAS.
Pengambilan data kedua dilakukan satu hari sebelum siswa menhadapi PAS. Pengambilan data tersebut dilakukan dua kali untuk mengetahui perbedaan tingkat kesiapan siswa ketika rentang waktu menuju penilaian masih jauh dan rentang waktu penilaian sudah dekat.

Berdasarkan data yang diperoleh menunjukkan adanya perbedaan kesiapan siswa pada saat waktu penilaian masih 2 pekan lagi dengan kesiapan siswa pada saat waktu penilaian 1 hari lagi. Siswa yang mengikuti bimbel memiliki kesiapan yang tinggi saat PAS masih 2 pekan lagi, sedangkan siswa yang tidak mengikuti bimbel menunjukkan belum memiliki kesiapan. Ketika waktu PAS semakin dekat saat 1 hari sebelum penilaian, siswa yang mengikuti bimbel dan yang tidak memiliki kesiapan yang sama dalam menghadapi PAS biologi.

Siswa yang mengikuti bimbel, pada data 2 pekan sebelum penilaian terlihat sangat siap dalam menghadapi PAS. Aspek kesiapan yang mendominasi adalah aspek kesiapan fisik $(19,97 \%)$ dan aspek kesiapan pengetahuan $(21,43 \%)$. Sedangkan yang tidak mengikuti bimbel memiliki tingkat kesiapan fisik sebesar $11,78 \%$ dan tingkat kesiapan pengetahuan sebesar 13,09\%. Hal ini terjadi karena adanya pembiasaan yang dilakukan di kegiatan bimbel. Siswa yang mengikuti bimbingan belajar terbiasa menerima dan melakukan latihan soal, cara cepat menjawab soal yang sulit, pembelajaran materi dengan menekankan pemahaman konsep. Hal ini sejalan dengan hasil penelitian (Arsyad, 2017; Khafid, 
2017; Nurhikmalasari, 2016; Tarwiyah, 2012; Nurlinggasari, 2017; Amalia, 2018; Nihayah, 2018; Thahir \& Hidriyanti, 2014; Wulan Sari, 2015) yang mengatakan bimbingan belajar membantu siswa memahami pelajaran dengan baik, meningkatkan motivasi, dan minat terhadap pelajaran, sehingga dalam berbagai kondisi siswa yang mengikuti bimbel lebih siap ketika akan menghadapi penilaian.

Sedangkan pada data yang diambil 1 hari sebelum PAS, ternyata hasil perhitungan dengan Smith-Satterthwaite tidak terdapat pengaruh yang signifikan antara siswa yang mengikuti bimbingan belajar dengan kesiapan menghadapi PAS biologi. Hal ini diduga, karena 1 hari menjelang PAS tersebut, seluruh responden memang mempersiapkan diri untuk menghadapi PAS tersebut. Kondisi ini bisa disebabkan karena adanya informasi nilai KKM yang cukup tinggi yaitu 80, untuk mata pelajaran Biologi, sehingga muncul keinginan untuk memperoleh nilai tersebut dan menghindari remedial.

Namun demikian, berdasarkan Tabel 1, terlihat adanya perbedaan dari masingmasing kesiapan yang diungkapan (Wahyuni, 2016) ada beberapa faktor yang mempengaruhi kesiapan siswa dalam menghadapi penilaian, diantaranya kesiapan fisik, kesiapan mental, kesiapan emosional, kesiapan kebutuhan dan kesiapan pengetahuan. Bimbingan belajar memberikan persiapan-persiapan tersebut lebih baik.

Terkait kecilnya persentase pengaruh keikutsertaan siswa dalam bimbingan belajar terhadap kesiapan siswa menghadapi penilaian ini bisa saja datang dari faktor lain. Sejalan dengan hasil penelitian (Nurhikmalasari, 2016) bahwa faktor lain yang berasal dari siswa itu sendiri misalnya intelegensi, minat, bakat, emosi serta motivasi yang miliki siswa tersebut. Adapun faktor luar yang ikut mempengaruhi kesiapan siswa yaitu keluarga, sekolah, masyarakat, dan linkungan sekitar yang dekat dengan siswa itu sendiri.

\section{KESIMPULAN}

Berdasarkan hasil penelitian maka dapat disimpulkan bahwa tidak terdapat pengaruh antara siswa yang mengikuti bimbingan belajar dengan kesiapan siswa menghadapi ujian. Pengaruh sangat terlihat pada pengambilan data 2 pekan sebelum PAS, tidak terlihat pada pengambilan data 1 hari sebelum PAS.

\section{DAFTAR PUSTAKA}

Ahmad, N. (2015). Buku Ajar Evaluasi Pembelajaran (Pertama). Yogyakarta: Interpena.

Amalia, D. C. F. (2018). Pengaruh Keikutsertaan Bimbingan Belajar Terhadap Hasil Belajar Siswa Kelas VI SDIT Salsabila 3 Banguntapan. UIN Sunan Kalijaga.

Arifin, Z. (2012). Evaluasi Pembelajaran Penulis (Edisi Revi). Dirjen Pendidikan Islam Kemenag.

Arsyad, A. W. (2017). Pengaruh Bimbingan Belajar Luar Sekolah terhadap Prestasi Belajar Siswa. Jurnal SOSIALISASI Pendidikan Sosiologi-FIS UNM, 4(1), 1-4.

Asrul, Rusydi, A., \& Rosinta. (2015). Evaluasi Pembajalaran (Kedua). Bandung: Citapustaka Media.

Berg, G. A. (2010). Cases on online tutoring, mentoring, and educational services: Practices and applications. In IGI Global. https://doi.org/10.4018/978-1-60566876-5

Depdiknas. (2003). Undang-undang Republik Indonesia Nomor 20 tentang Sistem Pendidikan Nasional. Jakarta: Depdiknas.

Isaacs, T., Zara, C., Herbert, G., Coombs, S. J., \& Smith, C. (2013). Key Concepts in Educational Assessment. In SAGE Publications. London: Sage.

Kemendikbud. (2016). Salinan Permendikbud Nomor 23 tahun 2016 
Tentang Standar Penilaian

Pendidikan. Jakarta: Kemendikbud.

Khafid, M. (2017). Efektivitas Bimbingan

Belajar dalam Meningkatkan Hasil

Belajar SiswaKelas XI MIA Mata

Pelajaran Sejarah di MAN

Gondanglegi Kab Malang. UIN

Maulana Malik Ibrahim.

Mulyani, D. (2013). Hubungan Kesiapan

Belajar Siswa Dengan Prestasi

Belajar. KONSELOR: Jurnal Ilmiah

Konseling, 2(1), 27-31.

https://doi.org/10.24036/0201321729-

0-00

Nihayah, N. (2018). Pengaruh Bimbingan

Belajar terhadap Kejenuhan dalam

Belajar pada Siswa Kelas XI di

SMAN I Gerung Kabupaten Lombok

Barat. EL-HIKMAH: Jurnal Kajian

Dan Penelitian Pendidikan Islam,

12(1), 53-64.

https://doi.org/10.20414/elhikmah.v12 i1.241

Nurhikmalasari. (2016). Pengaruh

Program Bimbingan Belajar

Terhadap Hasil Belajar Ekonomi

Siswa. UIN Syarif Hidayahtullah.

Nurlinggasari, D. (2017). Hubungan Bimbingan Belajar di Luar Sekolah dan Motivasi Belajar dengan Prestasi Belajar Biologi. Universitas Lampung.

Rizki, U. Y. (2013). Hubunga Kesiapan Belajar Dengan Optimisme Mengerjakan. Educational Psychology Journal, 2(1), 49-56.

Sinta B, V. (2017). Pengaruh Kesiapan Belajar Terhadap Hasil Belajar Mata Pelajaran Ekonomi Kelas X Di Sma Bina Jaya Palembang. UTILITY: Jurnal Ilmiah Pendidikan Dan Ekonomi, Volume 1,(1), 11-20. Retrieved from http://journal.stkipnurulhuda.ac.id/ind ex.php/utility

Suhandis, Junaidi, Matsum, H. M., \& Asrati, N. (2014). Pengaruh
Bimbingan Belajar Dan Motivasi

Belajar Terhadap Hasil USBN Mata

Pelajaran Ekonomi Kelas XII IPS

MAN Kubu Raya. 1-11.

Tarwiyah, V. J. (2012). Pengaruh

Bimbingan Belajar dalam

Meningkatkan Prestasi Belajar

Peserta Didik Kelas VIII MTs Negeri

Godean, Sleman, Yogaykarta. UIN

Sunan Kalijaga.

Thahir, A., \& Hidriyanti, B. (2014).

Pengaruh Bimbingan Belajar

Terhadap Prestasi Belajar Siswa

Pondok Pesantren Madrasah Aliyah

Al-Utrujiyyah Kota Karang. Konseli:

Jurnal Bimbingan Dan Konseling,

01(2), 63-76. Retrieved from

http://ejournal.radenintan.ac.id/index. php/konseli/article/view/306/1202

Tyanurani, N. (2015). Komposisi Aspek Berbahasa dan Bersastra pada Soal

Ujian Akhir Semester Gasal Mata

Pelajaran Bahasa Indonesia Kelas

VII Tahun Pelajaran 2013/2014 di

SMP N 3 Sragen dan SMP N 1

Surakarta. Universitas

Muhammadiyah Surakarta, Surakarta.

Wahyuni, H. (2016). Kesiapan Siswa dalam Menghadapi Ujian Tengah

Semester Genap pada Mata Pelajaran

Sejarah Di Kelas Xi IPS SMA Negeri

1 Gunung Tuleh (Vol. 1).

SekolahTinggi Keguruan dan Ilmu

Pendidikan PGRI Sumatra Barat.

Wulan Sari, Y. (2015). Pengaruh

Bimbingan Belajar Terhadap Hasil

Belajar Matematika Siswa Kelas Iv Di

Sekolah Dasar. Jurnal Penelitian

Pendidikan Guru Sekolah Dasar, Vol. 3.

Yusuf, S., \& Nurihsan, A. J. (2005).

Landasan Bimbingan \& Konseling.

Bandung: Remaja Rosdakarya. 